\title{
Saat Rakyat Bicara: Demokrasi dan Kesejahteraan
}

\author{
Bagir Manan', Susi Dwi Harijanti²
}

\begin{abstract}
Abstrak
Secara tradisional, kesejahteraan adalah suatu kepercayaan bahwa kesejahteraan sosial merupakan tanggung jawab dari masyarakat dan tanggung jawab ini harus dipenuhi oleh pemerintah yang dilaksanakan dalam bentuk negara atau sistem pemerintahan. Demokrasi masih dipandang sebagai sistem yang paling sesuai dalam rangka tercapainya kesejahteraan sosial karena demokrasi memberikan jalan bagi rakyat untuk berbicara. Namun, pada praktiknya demokrasi oleh masyarakat awam kerapkali diartikan sebagai pemerintah yang sebenarnya lebih menekankan kepada demokrasi politik. Artikel ini akan memperlihatkan bagaimana kesejahteraan sosial dianalisis secara akurat dari pemikiran mengenai demokrasi sosial yang berjalan beriringan dengan model demokrasi konsensus sebagai dasar fundamental dalam menghadapi peristiwa negara dan pemerintahan.
\end{abstract}

Kata Kunci: demokrasi, demokrasi sosial, kesejahteraan, model demokrasi konsensus, sejahtera.

\section{Time for People to Speak: Democracy and Welfarism}

\begin{abstract}
Traditionally, Welfarism is the belief that social well-being is the responsibility of a community which could only be realized through state or governmental management. It is still believed that Democracy is the most proper system in achieving social welfare, since it permits the people of a country to speak. In practice, however, Democracy is only understood as a system that gives the governmental rights to the majority of the people. This article, thus, will argue that social welfare is more precisely analyzed through the notion of Social-Democracy, which goes hand-in-hand with the consensus model of Democracy as a fundamental base in carrying out state and governmental affairs.
\end{abstract}

Keywords: democracy, social democracy, welfarism, consensus model of democracy, welfare.

1 Guru Besar Tidak Tetap Fakultas Hukum Universitas Padjadjaran, S.H.(Universitas Padjadjaran), MCL (Southern Methodist University Dallas Texas), Dr. (Universitas Padjadjaran).

2 Dosen Hukum Tata Negara Fakultas Hukum Universitas Padjadjaran, JI. Dipati Ukur No. 35 Bandung, S.H.(Universitas Padjadjaran), LL.M (The University of Melbourne Australia), Ph.D. (The University of Melbourne Australia). 


\section{A. Pendahuluan}

Paham kesejahteraan secara tradisional merupakan suatu keyakinan bahwa kesejahteraan rakyat adalah tanggung jawab masyarakat dan bahwa tanggung jawab tersebut terpenuhi melalui pemerintah. ${ }^{1}$ Pemenuhan tersebut direalisasikan dalam bentuk penyelenggaraan negara atau pemerintahan yang populer disebut sebagai negara kesejahteraan (the welfare state). Setelah tahun 1945, "konsensus kesejahteraan" dibangun di negara-negara demokrasi liberal barat yang melibatkan partai-partai aliran kiri, kanan dan tengah yang mencoba meneguhkan mandat mereka, tetapi mereka tidak bersepakat terhadap hal-hal detail berkenaan dengan pembiayaan, struktur, serta organisasi untuk mewujudkan kesejahteraan tersebut. ${ }^{2}$ Di Indonesia, pada tahun 1945, para pendiri bangsa dan perumus undang-undang dasar juga tidak luput membahas perihal kesejahteraan. Hasilnya, kesejahteraan umum menjadi salah satu tujuan negara Indonesia sebagaimana tercantum dalam Pembukaan UUD 1945, yang kemudian dielaborasi dalam Bab XIII mengenai Kesejahteraan Sosial, yang terdiri atas Pasal 33 dan Pasal 34. Setelah perubahan, kesejahteraan diatur bersamaan dengan perekonomian dalam Bab XIV.

Dalam upaya pencapaian kesejahteraan, dari berbagai sistem penyelenggaraan negara, demokrasi dengan berbagai kelebihan dan kekurangannya, masih dipandang sebagai sistem yang terbaik. Demokrasi memungkinkan rakyat bersuara dan rakyat yang dimaksud adalah seluruh rakyat (all the people). Hal itu dapat terjadi karena secara umum demokrasi digambarkan sebagai pemerintahan dari rakyat, oleh rakyat dan untuk rakyat (government of the people, by the people, for the people). Suatu ungkapan yang disampaikan oleh Presiden Abraham Lincoln dalam pidato 19 November 1863 di Gettysburg, Pennsylvania. ${ }^{3}$

Namun, dalam praktiknya, pemerintahan oleh rakyat sering kali diterjemahkan sebagai pemerintahan oleh mayoritas atau "government by the majority of the people". ${ }^{4}$ Bahkan secara ekstrem dikatakan bahwa minoritas bertindak sebagai pihak oposisi. ${ }^{5}$ Pertanyaannya, apakah pemerintahan oleh mayoritas dapat mewujudkan kesejahteraan? Pertanyaan tersebut patut dilontarkan karena sebagai bentuk

1 Andrew Heywood, Political Theory, Hampshire: Palgrave MacMillan, 2004, hlm. 306.

2 Ibid.

3 Abraham Lincoln, The Gettysburg Address, England: Penguin Books, 2009, hlm. 116. Menariknya, Clifford D. May sebagaimana dikutip oleh Arend Lijphart mengatakan definisi yang dikemukakan oleh Lincoln sebenarnya telah diutarakan oleh Daniel Webster - 33 tahun sebelum Gettysburg Address - la mengatakan "a people"s government, made for the people, made by the people, and answerable to the people". Arend Lijphart, Patterns of Democracy: Government Forms and Performance in Thirty-Six Countries, New Haven \& London: Yale University Press, 2012, hlm. 1.

4 Ibid., hlm. 30.

5 Ibid. 
penyelenggaraan negara, demokrasi diharapkan dapat membawa pada tercapainya tujuan bernegara, yaitu sebesar-besarnya kesejahteraan rakyat.

Konsep government by the majority memperoleh kritikan yang sangat tajam dari Sir Arthur Lewis - penerima hadiah Nobel bidang ekonomi - yang secara singkat mengatakan:

"The primary meaning of democracy is that all who are affected by a decision should have the chance to participate in making that decision either directly or through chosen representative. Its secondary meaning is that the will of the majority shall prevail. If this means that the winning parties may make all the governmental decisions and that the losers may criticize but not govern... the two meanings are incompatible...to exclude the losing groups from participation in decision-making clearly violates the primary meaning of democracy". 6

Jika beranjak dari pandangan Lewis di atas, maka pertanyaan selanjutnya adalah jenis demokrasi apa yang "compatible" dengan kesejahteraan? Artikel ini secara khusus membahas demokrasi sosial dan demokrasi konsensus sebagai upaya mencapai kesejahteraan. Analisis ini mencakup pula demokrasi di Indonesia. Paparan-paparan dalam tulisan ini terbagai menjadi beberapa bagian. Setelah Pendahuluan, bagian B akan memuat penjelasan mengenai pengertian dan perkembangan demokrasi, yang dilanjutkan dengan paparan mengenai demokrasi sosial dan demokrasi konsensus sebagai dasar kesejahteraan sebagaimana dimuat dalam bagian C. Penjelasan mengenai cita-cita demokrasi Indonesia akan dilakukan di bagian D. Penutup tulisan akan dimuat dalam bagian $\mathrm{E}$.

\section{B. Demokrasi: Pengertian dan Perkembangannya}

Secara umum diketahui bahwa demokrasi pertama kali berkembang di Yunani Kuno, yang terdiri dari dua kata "demos" dan "cratein". Namun dari studi yang dilakukan oleh John Keane diketahui bahwa kata demokrasi berusia lebih tua dari Yunani Kuno.? Akar kata demokrasi dapat ditelusuri dari "the Linear B script" pada periode Mycenaean (c. 1500-1200 BCE) yang berpusat pada Mycenae dan tempat-tempat pemukiman di Peloponnese. Belum dapat diketahui dengan pasti bagaimana dan kapan masyarakat Mycenae menggunakan kata "damos" atau "damokoi". Bahkan lanjut Keane, kata demokrasi yang digunakan saat ini - meskipun belum jelas ditemukan dalam bahasa Sumeria Kuno "dumu". Namun ketidakjelasan itu justru diperjelas oleh penemuan luar biasa para arkeolog yang memperlihatkan bahwa

6 Ibid.

7 John Keane, The Life and Death of Democracy, London-Sydney-New York-Toronto: Pocket Books, 2010, hlm. xi. 
praktik demokrasi bukanlah inovasi asli Yunani, melainkan justru ditemukan di belahan Timur di wilayah-wilayah yang sekarang dikenal sebagai Syria, Irak, dan Iran. Di wilayah Timur, praktik ini kemudian berkembang ke India. Ke belahan Barat, praktik ini berkembang ke Byblos dan Sidon, kemudian Athena yang selama abad 5 SM diklaim sebagai hal unik yang berasal dari Barat. ${ }^{8}$ Dari perkembangan tersebut dapat dilihat bahwa sesungguhnya bangsa Barat melakukan "self-claim" yang luar biasa atas konsep demokrasi yang dikenal saat ini. Oleh karenanya, selama berabad-abad konsep demokrasi Barat inilah yang menyebar ke berbagai belahan dunia.

Sebagai suatu konsep yang senantiasa berkembang, tidak mudah memberikan pengertian demokrasi karena demokrasi mempunyai spektrum yang sangat luas. Maclver sudah mengingatkan bahwa demokrasi sebagai bentuk penyelenggaraan negara tidak pernah tercapai secara sempurna. ${ }^{9}$ Demokrasi berkembang menjadi beragam konsep. Misalnya, David Beetham menyatakan terdapat berbagai antithese yang didalamnya berisi konsepsi-konsepsi demokrasi yang tidak compatible, misalnya demokrasi sebagai deskriptif atau preskriptif konsep; demokrasi langsung vs demokrasi perwakilan; demokrasi elit vs demokrasi partisipasi; demokrasi politik vs demokrasi sosial, demokrasi dengan suara terbanyak vs demokrasi konsensus; demokrasi sebagai realisasi persamaan atau sebagai perbedaan yang dinegosiasikan. ${ }^{10}$

Secara politik, sebelum keruntuhan tembok-tembok negara komunis, dalam berbagai literatur atau tulisan, dijumpai pemakaian istilah western democracy dan eastern democracy. Pemakaian istilah tersebut tidak dimaksudkan untuk negara demokrasi yang dikembangkan dan dipakai di dunia Barat (yang semula diwakili Eropa), dan demokrasi yang dikembangkan dan dipakai di dunia Timur (yang diwakili Asia). Pemakaian istilah western democracy dan eastern democracy, bertalian dengan tatanan geopolitik yang disebut "Blok Barat" dan "Blok Timur". Blok Barat (Western Block) adalah blok negara-negara Barat non komunis yang dimotori Amerika Serikat, sedangkan Blok Timur dimotori Uni Soviet.

Dengan demikian, pengertian western democracy adalah demokrasi yang dipakai dan dikembangkan oleh negara Barat non komunis, sedangkan eastern democracy adalah demokrasi yang dikembangkan dan dijalankan pada negara-negara blok komunis. Pada negara-negara eastern democracy ada semacam doktrin untuk memberi kualifikasi dengan penamaan tertentu demokrasi yang mereka jalankan, seperti "demokrasi sentralisme" (di Uni Soviet), "demokrasi rakyat" di Tiongkok. Hal ini bertujuan untuk membedakan dengan demokrasi yang dijalankan pada negara-

8 Ibid.

9 R.M. Maclver, The Web of Government, New York: The Macmillan, 1961, hlm. 175.

10 David Beetham, Democracy and Human Rights, Cambridge: Polity Press, 1999, hlm. 1. 
negara Blok Barat. Negara eastern democracy menganggap demokrasi mereka yang lebih murni (genuine), sedangkan western democracy mereka pandang sebagai demokrasi semu, karena ada unsur-unsur "penindasan" kapitalistik. Pola semacam itu diikuti oleh beberapa negara baru di luar Blok Timur, tetapi yang tidak berkehendak mengikuti cara-cara demokrasi yang dipakai pada negara yang mengikuti sistem Blok Barat, termasuk "Demokrasi Terpimpin" ala Soekarno.

Tidak demikian halnya pada negara yang menjalani western democracy. Negaranegara tersebut beserta negara-negara lain yang cenderung pada sistem yang serupa, tidak lazim melekatkan suatu kualifikasi dengan nama-nama tertentu. Bagi mereka yang penting adalah menemukan kriteria-kriteria dasar (substansi) suatu demokrasi serta jaminan-jaminan prosedural pelaksanaannya.

Pemakaian kualifikasi tertentu, apalagi yang diikuti dengan nama tertentu ternyata sebagian merupakan cara-cara pembenaran untuk mereduksi nilai, pengertian, kriteria, dan mekanisme demokrasi yang bersifat umum atau universal. Di negara-negara seperti Uni Soviet, demokrasi tidak dijalankan. Bahkan negara itu menjalankan paham yang secara resmi disebut "diktator proletariat". Baik dalam doktrin (teori) maupun praktik, paham kediktatoran selalu berlawanan dengan demokrasi. Atau dengan kata lain, demokrasi dan kediktatoran atau totaliterisme merupakan dua ujung dalam spektrum politik. ${ }^{11}$

Sejalan dengan fakta di atas, abad 20 pada saat demokrasi dikatakan memperoleh kemenangan, justru membawa pada pembentukan rezim Komunisme dan Fasisme yang menyalahgunakan pemahaman dan praktik demokrasi. Kedua sistem tersebut justru menjalankan praktik pembersihan etnis (ethnics cleansing). ${ }^{12}$ Bahkan sosiolog Inggris, Michael Mann mengatakan "many modern regimes which claim to be democratic have exhibited a pronounced tendency towards ethnic and political cleansing". ${ }^{13}$ Hal semacam itu dapat terjadi karena kata "We the People" diterjemahkan sebagai "organic democracy" yakni "People" didefinisikan sebagai " $a$ unitary bloc in terms of opposition to an "Another" yang terdiri atas kaum minoritas dari suatu etnis, ras atau politik tertentu. ${ }^{14}$ Tidak mengherankan jika Mann mengatakan praktik genosida semacam itu sebagai sisi gelap demokrasi (the dark side

11 Gwendolen M. Carter dan John H. Herz, “Demokrasi dan Totaliterisme: Dua Ujung dalam Spektrum Politik” dalam Miriam Budiardjo (ed), Masalah Kenegaraan, Jakarta: PT Gramedia, 1980, hlm. 82. Tulisan tersebut merupakan terjemahan dari buku Carter \& Herz, Government and Politics in the Twentieth Century, Chapter II: "Democracy and Totalitarianism: Polar Points in the Political Spectrum", New York: F.A. Praeger, 1973. Alih bahasa oleh Amir Santoso. hlm. 12-27.

12 Ricardo Blaud dan John Schwarzmantel (eds), Democracy: A Reader, Edinburgh: Edinburgh University Press, 2006, hlm. 2 .

13 Ibid.

14 Ibid.

15 Ibid. 


\section{of democracy)..$^{15}$}

Berdasarkan pengalaman di atas perlu kehati-hatian untuk melekatkan suatu kualifikasi pada demokrasi yang hendak dijalankan. Selain unsur-unsur tetap yang bersifat universal, demokrasi mengakui kemajemukan kultural dan latar belakang sejarah setiap bangsa adalah suatu keniscayaan. Namun, faktor sosio kultural harus disesuaikan dengan prinsip umum demokrasi, karena tidak boleh meniadakan esensi demokrasi. Berdasarkan hal tersebut, dalam demokrasi selalu termuat unsur dinamik sehingga mampu merespons perkembangan masyarakat sekelilingnya. Oleh sebab itu tidak ada kebutuhan untuk memberikan kualifikasi untuk membedakan demokrasi yang satu dengan demokrasi yang lain. Ukuran kehadiran demokrasi tidak ditentukan oleh kualifikasi melainkan sejauhmana nilai-nilai dasarnya seperti kebebasan, persamaan, keterbukaan terwujud dalam kehidupan bermasyarakat, berbangsa dan bernegara.

Perkembangan-perkembangan di atas sesungguhnya secara nyata menampakkan realitas dari kompleksitas sistem politik modern dan globalisasi yang meningkat, yang pada gilirannya menghasilkan tantangan-tantangan baru dan signifikan terhadap demokrasi. ${ }^{16}$ Demokrasi dihadapkan pada berbagai persoalan mendalam, baik dari aspek teori maupun praktik. Kesulitan-kesulitan yang dihadapi tersebut umumnya muncul akibat adanya "conflicting demands" dari masyarakat yang sangat pluralistis, fenomena "politik identitas" (identity politics), dan skeptisme post-modern mengenai dasar-dasar universal demokrasi.

Dengan beragam kesulitan tersebut, salah satu tantangan terberat yang dihadapi demokrasi adalah sejauhmana demokrasi dapat mewujudkan kesejahteraan masyarakat. Bagian di bawah ini akan berisi uraian mengenai demokrasi dan kesejahteraan.

\section{Demokrasi Sosial dan Demokrasi Konsensus sebagai Dasar Kesejahteraan}

Sebagaimana telah disebutkan terdahulu bahwa paham kesejahteraan menghendaki peran pemerintah dan peran tersebut berwujud dalam penyelenggaraan negara atau pemerintahan yang secara popular dikenal sebagai negara kesejahteraan (the welfare state).Dari pengalaman beberapa negara Eropa, baik kalangan konservatif maupun liberal dan sosialis tidak menafikan ketertarikan mereka terhadap paham kesejahteraan, namun masing-masing menggunakan pertimbangan berbeda, yang berakibat pada perbedaan sistem pengaturan. ${ }^{18}$ Misalnya, kalangan konservatif

16 Ibid.

17 Ibid.

18 Andrew Heywood, op.cit, hlm. 307. 
mendekati kesejahteraan atas pertimbangan social cohesion dan national unity sebagaimana pengalaman di Inggris pada pertengahan abad 19 yang melakukan reformasi sosial yang acap kali dikaitkan dengan peran Benjamin Disraeli (1804-80), seorang negarawan dari Konservatif. ${ }^{19}$ Disraeli sangat mengkhawatirkan Inggris terpecah menjadi "two nations: the Rich and the Poor". ${ }^{20}$ Sebaliknya, kaum liberal mendekati kesejahteraan atas dasar prinsip-prinsip politik yang mengarah pada tercapainya dunia kebebasan individu. Meskipun pada mulanya reformasi sosial dikhawatirkan akan melemahkan inisiatif dan kerja keras, tetapi kaum liberal percaya bahwa reformasi tersebut justru akan menjadi jaminan tercapainya individual selfdevelopment. ${ }^{22}$ Pendekatan terhadap kesejahteraan yang dilakukan oleh kalangan sosial demokrat justru lebih jauh dibandingkan dengan kedua kalangan terdahulu. Hal itu terjadi karena pendekatannya menggunakan dua prinsip fundamental, yaitu communitarianism dan equality. ${ }^{23}$

Dalam perjalanan, penyelenggaraan negara tidak semata-mata bertumpu pada partisipasi rakyat. Artinya, demokrasi bukan semata-mata dilihat dari aspek politik, melainkan demokrasi diisi dengan paham sosial, yaitu demokrasi untuk kesejahteraan sosial (democratic welfare). Pemerintahan demokrasi adalah pemerintahan yang diselenggarakan rakyat demi kesejahteraan umum, yang disebut demokrasi sosial atau kolektivisme. Bonger menyebutnya sebagai demokrasi materil. ${ }^{24}$

Demokrasi sosial yang berkembang di Eropa pada awal abad ke-20 didorong oleh dua hal: pertama; pengaruh prinsip sosial - ekonomi Marxisme yang menghendaki sistem pemerataan dan pembagian pendapatan yang adil untuk seluruh rakyat. ${ }^{25}$ Kedua; sebagai upaya relaksasi kapitalisme sehingga lebih manusiawi (humanizing capitalism) dan menciptakan keseimbangan antara pasar dan negara, keseimbangan antara individu dan masyarakat. ${ }^{26}$ Dengan demikian, teori demokrasi sosial diciptakan untuk membuat sebuah kompromi antara, di satu pihak penerimaan terhadap kapitalisme sebagai satu-satunya mekanisme yang dipercaya untuk menciptakan kekayaan, dan di lain pihak keinginan untuk mendistribuskan kekayaan yang sejalan dengan prinsip-prinsip moral, bukan prinsip-prinsip pasar. ${ }^{27}$

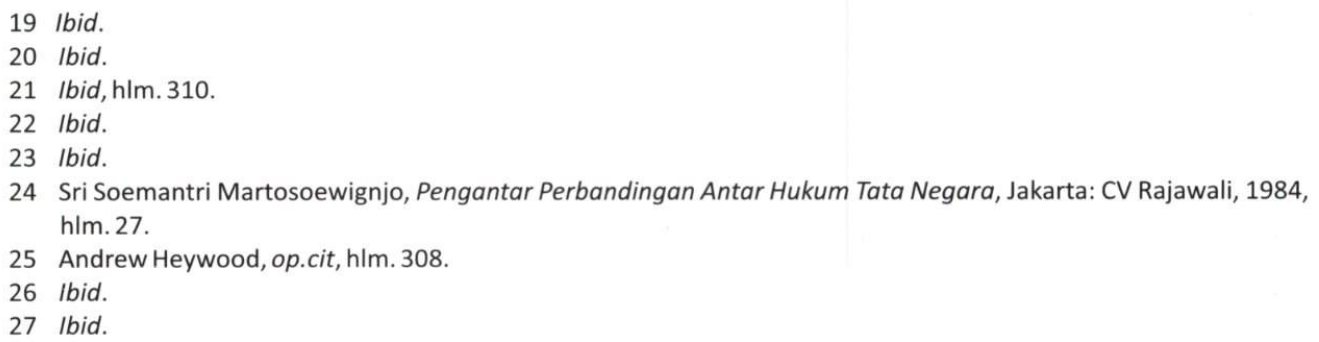


Karakteristik utama demokrasi sosial adalah concern terhadap golongan-golongan yang lemah dan rentan di masyarakat. ${ }^{28}$

Negara kesejahteraan merupakan bagian inti dari demokrasi sosial. ${ }^{29}$ Nilai-nilai dasar sosial demokrasi adalah kebebasan, keadilan dan solidaritas, dan ketiga nilai tersebut merupakan konsepsi-konsepsi dasar negara kesejahteraan. Alexander Petring menggunakan hasil studi yang dilakukan oleh Gøsta Esping-Andersen yang membagi tiga jenis negara kesejahteraan, ${ }^{30}$ yaitu liberal (umumnya negara-negara Anglo Saxon), konservatif (merujuk ke Kontinental) dan sosial demokratik (umumnya negara-negara Skandinavia) yang didasarkan pada dua kriteria utama sebagai pembanding: decommodification dan stratification. ${ }^{31}$ Kriteria pertama menunjuk sejauh mana kehidupan seseorang terjamin tanpa ketergantungan pada pasar ketenagakerjaan sedangkan stratifikasi menggambarkan lapisan-lapisan masyarakat (social layers).

Liberal welfare state mengandalkan peran pasar dalam usaha pencapaian kesejahteraan pada saat hak-hak sosial dan aturan-aturan sosial baru muncul belakangan. ${ }^{32} \mathrm{Di}$ negara-negara semacam ini, pembiayaan-pembiayaan sosial bersandar dari pajak dan tidak terdapat perbedaan antara berbagai jenis pekerjaan ataupun perbedaan tingkat penghasilan. Karena hanya tersedia jaminan sosial yang bersifat minimal yang bertujuan mencegah kemiskinan, maka bagi mereka yang mampu akan menggunakan penyedia jasa swasta, misalnya asuransi swasta ataupun sekolah-sekolah swasta. Akibatnya, secara tidak langsung tercipta stratifikasi antara si kaya dan si miskin. Amerika Serikat, Inggris dan Australia merupakan contoh-contoh negara dalam kategori ini.

Conservative welfare state yang kadang-kadang disebut sebagai corporatis welare state mendasarkan pembiayaan pada kontribusi (contribution) berdasarkan "assessment ceilings", yakni melihat pada batas penghasilan yang menentukan keharusan besaran pembayaran kontribusi. ${ }^{33}$ Mereka yang tergabung dalam asosiasi pekerjaan profesional tertentu, misalnya, pengacara, konsultan pajak, dokter hewan, notaris, dan akuntan, biasanya menerima asuransi pensiun yang berbeda dengan asuransi serupa yang ditetapkan berdasarkan undang-undang. Assessment ceilings di atas, antara lain, mengakibatkan ketidaksetaraan perlakuan terutama pada hal-hal yang berkaitan dengan perbedaan antara asuransi yang didasarkan pada undangundang dengan asuransi swasta. Selain itu, di negara-negara ini terdapat

28 Ibid.

29 Alexander Petring, et., al, Welfare State and Social Democracy, Berlin: Friedrich Ebert Stiftung, 2012 , hlm. 8.

30 Ibid.

31 Ibid, hlm 35-36.

32 Ibid, hlm 36.

33 Ibid, hlm 37-39. 
kecenderungan model bahwa laki-laki merupakan pencari nafkah tunggal (the male single-earner model). Akibatnya tenaga kerja perempuan rendah dan oleh karenanya keberadaan tempat penitipan anak minim. Contoh negara-negara yang menganut sistem ini adalah Jerman, Perancis, dan Belgia.

Social democratic welfare state dalam hal pembiayaan serupa dengan liberal welfare state, yakni melalui pajak yang sangat tinggi. ${ }^{34}$ Umumnya biaya untuk keperluan sosial lebih tinggi di negara demokrasi sosial, dibandingkan dengan negara liberal. Selain itu, pelayanan publik dapat diakses oleh masyarakat, tanpa melihat apakah mereka bekerja atau tidak. Penyerapan tenaga kerja perempuan relatif tinggi dibandingkan dengan tipe negara kesejahteraan yang konservatif karena terdapat semacam"rekonsiliasi" antara pekerjaan dan kehidupan keluarga karena negara menyediakan berbagai fasilitas perawatan dan perlindungan, misalnya tempat penitipan anak dan kesehatan. Negara-negara Skandinavia (Swedia, Denmark, dan Norwegia) merupakan contoh negara dalam jenis ini.

Meskipun demokrasi sosial diyakini sebagai salah satu jenis demokrasi yang sangat berdekatan dengan kesejahteraan, tetapi dalam pelaksanaannya membutuhkan mekanisme politik. Demokrasi konsensus dianggap sebagai mekanisme yang tepat, terutama di negara-negara dengan tingkat kemajemukan tinggi karena demokrasi ini mempunyai beberapa karakteristik, meliputi inklusif (inclusiveness), adanya "tawar menawar" (bargaining), serta kompromi (compromise). ${ }^{35}$ Untuk alasan-alasan tersebut, demokrasi konsensus sering diistilahkan dengan "negotiation democracy".

Sebagaimana telah disebutkan pada bagian Pendahuluan, demokrasi konsensus muncul sebagai kritik terhadap demokrasi mayoritas. Jika masyarakat sangat heterogen, tetapi demokrasinya adalah demokrasi mayoritas maka akan berakibat pada timbulnya kediktatoran mayoritas. Hal tersebut bukan saja tidak demokratis, melainkan juga berbahaya karena kalangan minoritas yang tidak mempunyai akses terhadap kekuasaan akan merasa tersingkir dan terdiskriminasi. ${ }^{36}$

Dalam penjelasannya mengenai demokrasi konsensus, Arend Lijphart menggunakan dua dimensi utama, yang masing-masing terdiri atas lima elemen atau karakteristik. ${ }^{37}$ Dimensi pertama disebutnya sebagai dimensi kekuasaan eksekutifpartai yang meliputi hal-hal berkaitan dengan cabang kekuasaan eksekutif, partai politik dan sistem pemilihan umum, serta golongan kepentingan. Ke dalam dimensi ini terdapat elemen-elemen sebagai berikut:

\footnotetext{
34 Ibid, hlm. 39-40.

35 Arend Lijphart, op., cit, hlm. 2.

36 Ibid, hlm. 32.

$37 \mathrm{lbid}, \mathrm{hlm} .3-4$.
} 
1. Kekuasaan eksekutif yang didasarkan pada koalisi multi partai (executivepower sharing in broad multiparty coalitions);

2. Keseimbangan kekuasaan antara eksekutif dan legislatif (executive-legislative balance of power);

3. Multi partai sistem (multiparty system);

4. Sistem pemilu proporsional (proportional representation); dan

5. Sistem golongan kepentingan yang terkoordinasi yang bertujuan mencapai kompromi.

Sedangkan dimensi kedua adalah "federal-unitary dimension", yang meliputi elemenelemen sebagai berikut:

1. Pemerintahan federal dan desentralisasi;

2. Pembagian kekuasaan antara dua kamar badan legislatif yang mempunyai kekuasaan yang sama kuat;

3. Konstitusi yang bersifat rigid yang hanya dapat diubah melalui mayoritas mutlak;

4. Konstitusionalitas undang-undang diperoleh melalui pengujian hukum yang dilakukan oleh Mahkamah Agung atau Mahkamah Konstitusi; dan

5. Bank sentral yang independen.

Dengan demikian, konsensus demokrasi yang dijelaskan oleh Lijphart memiliki karakteristik-karakteristik: sharing power melalui koalisi kabinet pemerintah, sistem pemilihan proporsional, sistem multi partai, pemerintahan federal dan desentralisasi, strong bicameralism, judicial review, serta independensi bank sentral. ${ }^{38}$

Bagaimanakah pandangan para pendiri bangsa dan perumus UUD mengenai demokrasi saat Indonesia merdeka? Bagaimana pula pelaksanaan demokrasi sebagai asas dan mekanisme dalam upaya pencapaian tujuan bernegara? Bagian di bawah ini akan menjelaskan kedua hal tersebut.

\section{Demokrasi Indonesia Merdeka: Cita-cita dan Implementasi}

Baik pada masa pergerakan maupun pada saat penyusunan UUD Indonesia merdeka, semua sependapat, agar demokrasi atau paham kedaulatan rakyat menjadi salah satu sendi Indonesia merdeka. Diakui ada berbagai visi di antara para anggota pergerakan dan penyusun UUD. Namun ada yang membangun paham demokrasi bagi Indonesia merdeka dari prinsip-prinsip ajaran agama (khususnya Islam) seperti prinsip permusyawaratan dari Yamin dan Agus Salim. Ada pula yang menggali prinsip-prinsip

38 Lihat Adrian Vatter, "Lijphart Expanded: Three Dimensions of Democracy in Advanced OECD Countries?", European Political Science Review, 2009, hlm. 126.

http://www.ipw.unibe.ch/content/team/e2425/e6965/e8618/e9123/e9128/Vatter.20009_ger.pdf, diunduh 5 Mei 2014. 
demokrasi dari adat-istiadat Indonesia yang dipadukan dengan paham demokrasi modern seperti diutarakan oleh Hatta dan Soekarno. Ada juga semata-mata melihat dari budaya asli Indonesia seperti Soepomo. Tentu ada yang hendak menjalankan prinsip demokrasi sebagaimana telah berjalan pada berbagai negara Barat, termasuk yang berlaku di Negara Belanda.

Perbedaan-perbedaan pendekatan tersebut tidak mengurangi persamaan pendirian mereka mengenai corak demokrasi yang hendak dijalankan dalam Indonesia merdeka. Persamaan itu meliputi:

Pertama; paham demokrasi tidak hanya diartikan sebagai suatu sistem politik, tetapi juga sistem ekonomi. Dengan kata lain, demokrasi sekaligus meliputi demokrasi politik dan demokrasi ekonomi. Soekarno menyebut demokrasi ini sebagai "sociodemocratie". Sesungguhnya, pada tahun 1941 dalam surat kabar "Pemandangan", Soekarno menulis dengan judul "Demokrasi Politik dengan Demokrasi Ekonomi = Demokrasi Sosial", yang berisi antara lain:

"Karena itu ternyatalah bahwa untuk membuat sejahteranya rakyat jelata, politieke democratie atau parlementaire democratie sahaja belumlah cukup. Masih perlu lagi ditambah dengan demokrasi di lapangan lain, kerakyatan di lapangan lain, kesama-rasa-sama-rataan di lapangan lain. Lapangan lain ini ialah lapangan rezeki, lapangan ekonomi. Demokrasi politik sahaja belum cukup-yang mencukupi ialah demokrasi politik plus demokrasi ekonomi" ${ }^{39}$ Sejalan dengan pemikiran di atas, Mohammad Hatta menyatakan:

“....Demokrasi politik saja tidak dapat melaksanakan persamaan dan persaudaraan. Disebelah demokrasi politik harus pula berlaku demokrasi ekonomi. Kalau tidak, manusia belum merdeka. Sebab itu, cita-cita demokrasi Indonesia ialah demokrasi sosial, meliputi seluruh lingkungan hidup yang menentukan nasib manusia". ${ }^{40}$

Hatta menamakan sebagai "demokrasi sosial" atau "kolektivisme", yang didasarkan pada tiga sumber yaitu, ${ }^{41}$

1. Paham sosialis Barat yang membela dasar-dasar kemanusiaan;

2. Ajaran Islam yang menuntut keadilan dan kebenaran dan persaudaraan antar manusia; dan

3. Dasar kolektivisme masyarakat Indonesia.

Demokrasi politik akan menjelma dalam berbagai kelembagaan politik baik pada tingkat supra struktur maupun infrastruktur sedangkan demokrasi ekonomi

39 Soekarno, Di bawah Bendera Revolusi, Jakarta: Panitia Penerbit Dibawah Bendera Revolusi, 1965, hlm. 579.

40 Mohammad Hatta, Demokrasi Kita, Jakarta: Balai Pustaka, 2004, hlm. 28.

41 Endang Basri Ananda dan Sori Siregar (Penyunting), Karya Lengkap Bung Hatta, Buku 2: Kemerdekaan dan Demokrasi, Jakarta: LP3ES, 2000, hlm. 435. 
menjelma dalam bentuk sistem ekonomi yang disusun menurut asas kekeluargaan, yang secara kelembagaan menjelma dalam bentuk gerakan koperasi. Hal terakhir menunjukkan bahwa masalah kesejahteraan sosial ekonomi didekati dari paham demokrasi, bukan sebagai suatu bentuk hak asasi manusia (subsistence rights). Hal tersebut dapat dipahami karena paham hak asasi sosial (sociaal mensenrechten) belum menjadi perhatian. Pada saat itu kesejahteraan sosial ekonomi masih dipandang sebagai suatu corak demokrasi yang dikaitkan dengan prinsip persamaan yang disebut sebagai aspek materil dari demokrasi sebagaimana disebutkan oleh Bonger di atas. Namun apapun dasar yang diberikan, tidak mengurangi makna bahwa kesejahteraan sosial ekonomi merupakan salah satu pilar tujuan Indonesia merdeka. Oleh karena itu negara bertanggung jawab untuk mewujudkannya.

Kedua; dalam pengertian politik, disepakati, demokrasi yang hendak dijalankan bukanlah "duplikat" dari western democracy atau eastern democracy. Secara kelembagaan digunakan berbagai corak demokrasi modern seperti sistem perwakilan, kepartaian, dan pemilihan umum. Akan tetapi mekanismenya diangkat dari pranata sosial budaya asli seperti sistem permusyawaratan dalam pengambilan keputusan. Namun, bukan berarti tidak ada "hak berbeda pendapat" (the right to dissent). Hak berbeda pendapat tetap ada, tetapi dipadukan dalam sistem permusyawaratan sebagaimana dikemukakan oleh Agus Salim. Salah satu akibatnya, pelembagaan oposisi kurang mendapat perhatian. Tidak adanya pelembagaan oposisi, tidak selalu merupakan cacat untuk berdemokrasi secara sehat. Stelsel Congress Amerika Serikat tidak melembagakan oposisi seperti di Inggris, yang dikenal dengan nama loyal opposition. Komposisi oposisi setiap saat bergeser sesuai dengan masalah yang dihadapi (case by case). Dalam setiap demokrasi yang sehat tidak mungkin menolak atau meniadakan oposisi. Tanpa oposisi, akan meniadakan the right to dissent, yang merupakan salah satu hak asasi yang harus dijamin dan sekaligus sebagai konsekuensi dari prinsip kebebasan berpendapat (freedom of opinion).

Sebagai das sollen, usaha-usaha menemukan stelsel dan mekanisme demokrasi yang cocok bagi masyarakat Indonesia sangatlah dihargai. Namun, pada tataran das sein bukanlah sesuatu yang mudah dijelmakan. Hal itu disebabkan:

Pertama; perpaduan-perpaduan konseptual ternyata tidak disertai dengan penjabaran mengenai rule of the game yang juga menggambarkan perpaduan tersebut. Selain itu, tingkah laku politik turut memberikan kontribusi yang serius. Akibatnya, para pelaku demokrasi "bebas" menciptakan rule of the game menurut paham dan pengetahuan yang memengaruhi diri mereka serta keinginan-keinginan politik yang hendak dicapai. Oleh karenanya, dalam perjalanan dijumpai berbagai corak rule of the game. Dalam tataran penyelenggaraan pemerintahan memungkinkan berlaku sistem demokrasi parlementer dan sistem demokrasi 
presidensial. Pada tataran infrastruktur memungkinkan berlaku sistem multi partai dan non multi partai. Pada pemilihan umum memungkinkan sistem pemilihan proporsional, campuran, dan cukup kuat gagasan menerapkan sistem distrik. Bahkan kemudian muncul penamaan sebagai suatu bentuk kualifikasi seperti "Demokrasi Terpimpin" dan "Demokrasi Pancasila". Berbagai eksperimen tersebut ternyata menimbulkan berbagai keadaan yang excessive (berlebihan), baik dalam bentuk "ultra demokrasi" (berdemokrasi secara berlebihan) seperti yang dialami antara tahun 1945-1959, maupun suatu kediktatoran terselubung (verkapte diktatuur) dengan menggunakan nama demokrasi yang dikualifikasi (gekwalificeerde democratie). Selain itu, secara teori pembentukan kabinet koalisi yang terjadi pada masa reformasi, terutama sejak tahun 2004, tidak dapat diterima. Kabinet dalam sistem presidensial adalah zaken cabinet. Sayangnya, penganutan sistem presidensial bukan disertai dengan sistem dua partai, melainkan sistem banyak partai. Akibatnya, sebagaimana dijelaskan oleh Lijphart, koalisi menjadi tidak terhindarkan.

Kedua; demokrasi merupakan suatu mekanisme yang tidak mudah dan kompleks baik secara kelembagaan maupun mekanismenya. Demokrasi memerlukan kesabaran dan pengalaman. Berbagai kegagalan demokrasi di masa lalu antara lain karena kurangnya kesabaran dan pengalaman berdemokrasi termasuk pemecahan persoalan secara demokratis. Demokrasi bukan sekadar kebebasan tetapi tanggung jawab. Bung Hatta berulang-ulang menekankan aspek tanggung jawab dalam demokrasi. ${ }^{42}$ Demokrasi bukan sekedar tujuan (ends) tetapi tata cara (procedures). Dalam memahami demokrasi, antara tujuan dan cara merupakan two sides of one coin. Dalam demokrasi tidak boleh ada semboyan the end justifies the means. Kesulitan di atas yang berbentuk tidak ada kesabaran dan kurang pengalaman ditambah pula kenyataan adanya "watak kediktatoran dan semangat feodalisme" pada sebagian pemimpin pemerintahan yang dominan dan belum berkembangnya berbagai pranata sosial ekonomi dan lain-lain untuk lebih mendorong tumbuhnya masyarakat egaliter yang bersumber pada "kelas menengah" yang akan menjadi pelopor (spearhead) dan sekaligus penjaga (avant garde) demokrasi.

Dari berbagai pengalaman di atas, perlu disadari bahwa pertumbuhan demokrasi yang sehat tidak mungkin semata-mata diserahkan pada mekanisme politik. Demokrasi akan tumbuh sehat apabila ditunjang oleh pranata dan perkembangan sosial ekonomi yang menumbuhkan suasana sosial yang demokratis. Karena itu, agenda pengembangan demokrasi tidak boleh hanya berorientasi pada kelembagaan politik, tetapi juga berbagai kelembagaan sosial, ekonomi dan budaya, yang meliputi

$42 \mathrm{Ibid}, \mathrm{hlm} .440$. 
hal-hal sebagai berikut:

Pertama; Pendidikan.

Pendidikan merupakan instrumen pengembangan demokrasi yang sangat penting, yang akan meliputi baik aspek-aspek konseptual maupun penerapannya. Tujuan terpenting pendidikan demokrasi adalah menumbuhkan kesadaran berdemokrasi, mekanisme demokrasi yang sehat, keharusan ada tingkah laku yang demokratis seperti tanggung jawab, keadilan, transparansi, dan perdamaian.

Kedua; Pemberdayaan ekonomi rakyat.

Salah satu dasar sosial pertumbuhan demokrasi, apabila terdapat lapisan atau struktur kelas menengah yang kuat. Kelas menengah merupakan kelas yang paling dinamis dan moderat dibanding kelas "atas" dan kelas "bawah". Kelas atas mempunyai kecenderungan konservatif, karena itu anti segala bentuk perubahan atau pembaruan sedangkan demokrasi hanya dapat tumbuh dan bertahan secara wajar apabila senantiasa terjadi mobilitas baik secara horizontal maupun vertikal. Pergeseran politik, sosial, ekonomi dan lain-lain merupakan salah satu sendi dinamika dalam demokrasi. Hanya dengan proses dinamik tersebut akan terjadi berbagai penciptaan dan kreativitas. Lapisan bawah juga tidak dapat menopang demokrasi karena dalam serba keterbatasan gerak. Kalaupun suatu saat terjadi pergerakan dari kelas bawah, ada kecenderungan pada ekstremisme. Ekstremisme bukan unsur demokrasi, bahkan berlawanan dengan demokrasi. Ekstremisme dapat menghalalkan segala cara termasuk kekerasan. Demokrasi tidak mungkin ditegakkan dengan kekerasan. Demokrasi adalah suatu proses damai. Salah satu sumber penting kelas menengah adalah dari kekuatan ekonomi di samping dari dunia pendidikan. Oleh sebab itu, penting menciptakan sistem, struktur, dan kegiatan ekonomi yang mendorong tumbuhnya kelas menengah. Hal ini hanya mungkin apabila sistem dan struktur ekonomi dilandasi dan diarahkan pada pemberdayaan ekonomi rakyat, bukan ekonomi yang kapitalistis, konglomeratif, ataupun monopolistik yang hanya akan membangun bagian kecil kekuatan ekonomi masyarakat.

Ketiga; Perombakan struktur dan sikap feodalistis serta menumbuhkan budaya egaliter.

Di masa orde baru, terdapat berbagai struktur dan sikap feodalistis yang digunakan sebagai unsur untuk memberikan dan memperkokoh legitimasi yang bersifat mistis atas kekuasaan seseorang. Pemakaian gelar-gelar feodal dihidupkan kembali seperti Raden, Raden Mas, dan lain-lain, sehingga banyak anggota masyarakat yang mengidentifikasi diri mereka dengan unsur darah biru (kebangsawanan feodal). Demikian pula berbagai upacara yang bersifat feodal. Hal tersebut sangat mempengaruhi tingkah laku, baik penyelenggara negara, pemerintahan maupun 
masyarakat umum. Penyelenggara pemerintahan seringkali tidak menempatkan diri sebagai pamong yang melindungi dan melayani masyarakat, melainkan selaku pangreh yang berkuasa. Rakyat dipandang kaula yang harus mengabdi dan tunduk kepada kehendak pangreh, bukan sebagai warga yang sejajar dengan penyelenggara negara atau pemerintahan. Hubungan kekerabatan dan "perkoncoan" (spoil system) lebih dipentingkan daripada pertimbangan kecakapan (merit system). Kehendak yang memerintah lebih penting daripada hukum (above to the law), bukan sebagai yang harus tunduk pada hukum (subject to the law). Hanya rakyat yang wajib tunduk pada hukum. Sikap feodalistik ini merupakan salah satu sumber berkembangnya sikap dan praktek korupsi, kolusi, dan nepotisme, karena segala mekanisme kontrol dan hukum tidak dijalankan sebagaimana mestinya. Struktur dan sikap feodalistis bertentangan dengan tatanan demokrasi yang menghendaki struktur masyarakat egaliter bukan masyarakat berjenjang. Karena itu, untuk membangun suatu sistem demokrasi yang sehat diperlukan pula usaha membangun struktur masyarakat egaliter. Perbedaan antara rakyat dan penyelenggara negara dan pemerintahan tidak diletakkan dalam hubungan antara yang berkuasa (the ruling) dan yang dikuasai (the ruled), melainkan sekadar perbedaan fungsi antara yang bertugas melayani dan yang berhak menerima pelayanan. Penyelenggara negara dan pemerintahan adalah pamong bukan pangreh dan harus tunduk pada hukum dan kemauan rakyat banyak (yang berdaulat).

Keempat; Membangun supremasi hukum.

Pasal 1 ayat (3) UUD 1945 menyatakan bahwa negara Indonesia adalah negara hukum. Negara demokrasi berdasarkan atas hukum (democratische rechtstaat) merupakan dua sendi yang bersifat dwitunggal (two sides of one coin). Demokrasi tanpa disertai prinsip negara berdasarkan atas hukum merupakan suatu demokrasi yang semu, karena hukum tidak supreme sehingga tidak berfungsi mengendalikan kekuasaan. Secara kenyataan, demokrasi tanpa prinsip negara berdasarkan atas hukum adalah sebuah kediktatoran yang tersembunyi (verkapte dictatuur). Meskipun ada berbagai lembaga demokrasi, tetapi tidak berfungsi dengan layak. Misalnya, kekuasaan kehakiman yang merdeka sebagai suatu syarat negara berdasarkan atas hukum untuk menjamin fair trial, tidak berjalan karena dilanggarnya asas-asas seperti impartiality, due process, presumption of innocence, equality before the law, atau nonself incrimination. Kalaupun ada usaha menemukan kebenaran, sekadar menemukan kebenaran formal (formeie waarheid) bukan kebenaran materiil (materiële waarheid). Demikian pula hal yang berkaitan dengan hak asasi manusia, unsur-unsur partikularisme disalahgunakan untuk pembenaran penyimpangan atas hak asasi. Pembatasan hak asasi bukan berdasarkan atas hukum melainkan atas dasar penyalahgunaan arti "demi ketertiban dan keamanan", "demi kepentingan umum”, “demi pembangunan”, dan cara lain-lain untuk 
menyembunyikan kepentingan kekuasaan. Dalam negara semacam ini kepastian hukum tidak jarang diabaikan. Pemerintahan lebih banyak dilaksanakan berdasarkan kebijaksanaan (beleid) bukan berdasarkan atas hukum. Hal-hal itulah yang dapat terjadi dalam penyelenggaraan negara ataupun pemerintahan. Karena itu untuk mewujudkan demokrasi yang sehat, pelaksanaan segala prinsip negara berdasarkan atas hukum harus dilaksanakan secara tangguh dan konsekuen yang meliputi hal-hal seperti:

(1) Pelaksanaan prinsip negara berdasarkan konstitusi yang berintikan pembatasan kekuasaan. Bagi jabatan tertentu seperti Presiden harus ada pula pembatasan waktu maksimal memangku jabatan.

(2) Pelaksanaan fair trial, sebagai perwujudan kekuasaan kehakiman yang merdeka. Untuk itu harus dipegang teguh prinsip-prinsip seperti impartiality, due process, presumption of innocence, non-self-incrimination, prinsip mewujudkan keadilan dan bukan menerapkan hukum belaka, prinsip kebenaran materiil bukan sekedar kebenaran formal dan lain-lain. Penegak hukum bukan mulut undangundang tetapi mulut keadilan. Dalam rangka menjamin agar ketentuan hukum dan tindakan pemerintah senantiasa berdasarkan atas hukum atau dapat dibenarkan untuk mencapai suatu tujuan yang sah dan adil (based on the principle of justice), kekuasaan kehakiman harus dibenarkan (erken) atau dibiarkan (toelaten) untuk menilai atau menguji (toetsing, review), terhadap semua tindakan pemerintahan dan peraturan perundang-undangan yang berlaku.

(3) Pemerintahan diselenggarakan semata-mata berdasarkan atas ketentuan hukum, bukan berdasarkan beleid atau decree. Prinsip-prinsip doelmatigheid tidak boleh digunakan untuk mengesampingkan prinsip rechtmatigheid, kecuali benar-benar dapat ditunjukkan bahwa hal tersebut sangat diperlukan sebagai sesuatu yang terpaksa (compelling interest) untuk mencapai tujuan pemerintahan yang sah menurut prinsip negara berdasarkan atas hukum. Penggunaan prinsip Freis Ermessen atau discretionary power, harus dibatasi pada hal yang tidak melanggar asas penyelenggaraan administrasi negara yang baik (algemene beginselen van berhaoorlijk bestuur) yang tetap menjamin kepastian hukum, persamaan perlakuan, dan tidak bias (karena ada conflict of interest).

\section{E. Penutup}

Demokrasi memiliki dimensi sosial yang berarti demokrasi terutama bertalian dengan kesejahteraan umum. Demokrasi memikul tanggung jawab mewujudkan kesejahteraan umum atau keadilan sosial. Demokrasi yang sehat ditentukan pula 
oleh kondisi sosial, ekonomi, dan budaya masyarakat. Karena itu betapa penting menumbuhkan kondisi sosial, ${ }^{43}$ ekonomi, dan budaya yang kondusif bagi nilai-nilai demokrasi. Struktur masyarakat egaliter, kehadiran kelas menengah yang memadai, serta keterbukaan merupakan berbagai prasyarat bagi perkembangan demokrasi.

Dapat pula ditambahkan bahwa demokrasi merupakan suatu proses pendidikan, bukan sesuatu yang dapat diciptakan dalam waktu sekejap. Karena itu betapa penting proses pendidikan dan latihan berdemokrasi baik pada institusi sosial, ekonomi, budaya, apalagi pada institusi politik. Pendidikan dan latihan berdemokrasi dilakukan baik dalam bentuk kelembagaan maupun proses pengelolaan kelembagaan. Di atas segala itu, demokrasi hanya akan tumbuh kalau ada kesadaran berdemokrasi (democratic consciousness) dan sikap tanggung jawab dalam berdemokrasi (democratic responsibility) bahwa demokrasi bukan sekedar mengenai cara memperoleh kekuasaan tetapi sebagai sarana mewujudkan kesejahteraan umum dengan cara-cara yang demokratis. Demokrasi bukan kebebasan tanpa batas. Kebebasan demokrasi dibatasi oleh tanggung jawab terhadap kepentingan umum dan hukum, karena demokrasi adalah pemerintahan untuk kepentingan dan hanya dapat diwujudkan apabila dilaksanakan berdasarkan hukum (democracy under the rule of law).

Dalam konteks Indonesia, demokrasi sosial yang menjamin keadilan sosial, asas negara kekeluargaan serta menolak segala bentuk liberalisme dan individualisme merupakan dasar-dasar filosofis negara yang ditetapkan oleh para pendiri bangsa dan perumus UUD 1945. ${ }^{44} \mathrm{Hal}$-hal tersebut merupakan kandungan dasar UUD 1945 yang harus diikuti dan dilaksanakan. Dengan demikian, tidak menjalankan hal-hal tersebut - seperti kecenderungan pada liberalisme serta market oriented - tidak hanya merupakan penyimpangan, bahkan pelanggaran terhadap UUD $1945 .{ }^{45}$ Dalam rangka menjalankan demokrasi sosial, pilihan dijatuhkan pada demokrasi konsensus mengingat tingginya tingkat kemajemukan masyarakat yang harus dapat diwadahi dalam penyelenggaraan negara dan pemerintahan.

43 Bagir Manan, “Negara Hukum Indonesia (Berdasarkan UUD 1945)”, Makalah, 2011, hlm. 5.

44 Bagir Manan, "Menemukan Kembali Undang-Undang Dasar 1945", Pidato Mengakhiri Jabatan Guru Besar, Bandung, 6 Oktober 2011, hlm. 24.

45 Ibid. 


\section{Daftar Pustaka}

\section{Buku}

Beetham, David, Democracy and Human Rights, Polity Press, Cambridge, 1999.

Blaud, Ricardo dan John Schwarzmantel (eds), Democracy: A Reader, Edinburgh University Press, Edinburgh, 2006.

Miriam Budiardjo (ed), Masalah Kenegaraan, PT Gramedia, Jakarta, 1980.

Endang Basri Ananda dan Sori Siregar (Penyunting), Karya Lengkap Bung Hatta, Buku 2: Kemerdekaan dan Demokrasi, LP3ES, Jakarta, 2000.

Heywood, Andrew, Political Theory, Third Edition, Palgrave MacMillan, Hampshire, 2004.

Keane, John, The Life and Death of Democracy, Pocket Books, London-Sydney-New York-Toronto, 2010.

Lincoln, Abraham, The Gettysburg Address, Penguin Books, England, 2009.

Lijphart, Arend, Patterns of Democracy: Government Forms and Performance in Thirty-Six Countries, Second Edition, Yale University Press, New Haven \& London, 2012.

Maclver, R.M, The Web of Government, Cet. ke-19, The Macmillan, New York, 1961. Mohammad Hatta, Demokrasi Kita, Balai Pustaka, Jakarta, 2004.

Petring, Alexander, (et.al), Welfare State and Social Democracy, $2^{\text {nd }}$ updated edition, Friedrich Ebert Stiftung, Berlin, 2012.

Soekarno, Dibawah Bendera Revolusi, Jilid Pertama, Cet. Keempat, 1965.

Sri Soemantri Martosoewignjo, Pengantar Perbandingan Antar Hukum Tata Negara, CV Rajawali, Jakarta, 1984.

\section{Dokumen Lain}

Bagir Manan, Menemukan Kembali Undang-Undang Dasar 1945", Pidato Mengakhiri jabatan Guru Besar, Bandung, 6 Oktober 2011.

“Negara Hukum Indonesia (Berdasarkan UUD 1945)”, Makalah, 2011.

Vatter, Adrian, "Lijphart expanded: Three Dimensions of Democracy in Advanced OECD Countries?", European Political Science Review, 2009.

http://www.ipw.unibe.ch/content/team/e2425/e6965/e8618/e9123/e9128/V atter.2009_ger.pdf, diunduh 5 Mei 2014.

\section{Dokumen Hukum}

Undang-Undang Dasar Republik Indonesia Tahun 1945. 